\title{
CORRELATION BETWEEN DURATION OF GADGET UPTAKE AND QUALITY OF SLEEP IN STUDENT IN SENIOR HIGH SCHOOL IN YOGYAKARTA
}

\author{
Zadia Dara Cynintya Teha'), Dheska Arthya Palifiana'), \\ A.M Bandi Utama3) \\ ${ }^{1)}$ Masters Program in Public Health, Universitas Sebelas Maret \\ 2)Diploma IV of Teaching Midwivery, Universitas Respati Yogyakarta \\ 3)Universitas Negeri Yogyakarta
}

\begin{abstract}
Background: Empirical evidence demonstrates an association between sleep and the consolidation of cognitive performance, which is required for executive functioning including abstract reasoning, goal directed behavior, and creative processing. However, recent studies reported that excessive use of smartphones may reduce sleep time. Insufficient sleep, poor sleep quality, and sleepiness are common problems in children and adolescents being related to learning, memory and school performance. This study aimed to examine correlation between duration of gadget uptake and quality of sleep in senior high school students.

Subjects and Method: This was a cross sectional study carried out at Senior High School 1 in Depok, Sleman, Yogyakarta. A sample of 128 students was selected for this study randomly. The dependent variable was quality of sleep. The independent variable was duration of gadget use. Quality of life was measured by Pittsburgh Sleep Quality Index (PSQI). Duration of gadget use was measured by questionnaire. The data were analyzed using a multiple linier regression.

Results: Longer gadget use lowered quality of sleep in students 0.03 units and it was statistically significant $(b=0.03 ; 95 \% \mathrm{CI}=0.01$ to $0.05 ; \mathrm{p}=0.020)$.

Conclusion: Longer gadget use lower quality of sleep in students.
\end{abstract}

Keywords: gadget use, quality of sleep, senior high school students

Correspondence:

Zadia Dara Cynintya Teha. Diploma IV of Teaching Midwivery, Universitas Respati Yogyakarta. Jl. Raya Tajem 1.5, Sleman, Yogyakarta. Email: Cynintya@gmail.com Mobile: +6283857619108 . 